\title{
Entitlement, Process, and Legitimacy in the Emergent International Law of Secession
}

Obiora Chinedu Okafor

Osgoode Hall Law School of York University, ookafor@osgoode.yorku.ca

Source Publication:

International Journal of Minority and Group Rights. Volume 9, Issue 1 (2002), p. 41-70.

Follow this and additional works at: https://digitalcommons.osgoode.yorku.ca/scholarly_works c) (1) $(9)$

This work is licensed under a Creative Commons Attribution-Noncommercial-No Derivative Works 4.0 License.

\section{Recommended Citation}

Okafor, Obiora Chinedu. "Entitlement, Process, and Legitimacy in the Emergent International Law of Secession." International Journal of Minority and Group Rights 9.1 (2002): 41-70.

This Article is brought to you for free and open access by the Faculty Scholarship at Osgoode Digital Commons. It has been accepted for inclusion in Articles \& Book Chapters by an authorized administrator of Osgoode Digital Commons. 


\title{
Entitlement, Process, and Legitimacy in the Emergent International Law of Secession
}

\author{
OBIORA CHINEDU OKAFOR* \\ Osgoode Hall Law School, Toronto, Canada
}

'Living with differences ought to be a cardinal principle of all societies, but it must be abandoned when it results in repeated genocide.' Makau Mutua $^{1}$

'This term [legitimacy] is meant to designate the beliefs and attitudes that members have towards the [institutions] and society they make up.' Charles Taylor $^{2}$

\section{Introduction}

In 1996, the African Commission on Human and Peoples Rights ${ }^{3}$ issued its now famous decision in Katangese Peoples' Congress v. Zaire. ${ }^{4}$ About two years later, in 1998, the Supreme Court of Canada ${ }^{5}$ issued its equally famous decision in Reference Re Secession of Quebec. ${ }^{6}$ Both decisions addressed crucial and highly controversial questions regarding the right of a section of an existing country to secede. Both decisions concluded that the particular claimants of the secessionist entitlement in the extant cases were not entitled to secede from the states to which they currently belonged. However, both decisions also concluded that in a narrow range of exceptional cases, a discrete

* Assistant Professor of Law and SSRC-MacArthur Foundation Fellow on Peace and Security in a Changing World, Osgoode Hall Law School, York University, Toronto, Canada. The author would like to thank Antony Anghie, Obijiofor Aginam, James Gathii, and Karin Mickelson for their helpful comments on earlier versions of the paper, and Shedrack Agbakwa for his research assistance.

1 M. Mutua, 'Africans have Learned the Hard Way that Ethnic Rivalries cannot be Erased' The Boston Globe, 21 April 1999.

2 See C. Taylor, Reconciling Solitudes: Essays on Canadian Federalism and Nationalism (Montreal: McGill-Queen's University Press, 1993) at 64.

3 Hereinafter referred to as 'the African Commission'.

4 Communication No. 75/92, reproduced in (1996) 3 International Human Rights Reports 136 (hereinafter referred to as 'the Katanga Case').

5 Hereinafter referred to as 'the Supreme Court'.

6 (1998) 2 S.C.R. 217, hereinafter referred to as 'the Quebec Case'. 
section of an existing state would be entitled to secede from that state. This, however, is where the similarities between the two cases end.

Perhaps, the most important of the differences between the two cases relates to the alternative models of secessionist dispute management that are symbolized by the two cases. Each of them symbolizes a fundamentally different model. On the one hand, the Katanga case involved the reference of a secessionist dispute between a central government (Zaire) and one of its constituent units (Katanga/Shaba) to an international tribunal (the African Commission) that was a third party to the dispute. On the other hand, the Quebec Case involved the reference of a dispute between a central government (Canada) and one of its constituent units (Quebec) to a domestic tribunal (the Supreme Court) that functions as one of the three arms of that same central government. $^{7}$

This fundamental difference in the alternative models of secessionist dispute management that are symbolized by these two cases raises at least one very important set of questions regarding the legitimacy of processes and outcomes in the context of the management of an extremely high stakes ultrapolitical question ${ }^{8}$ such as a secessionist claim. This set of legitimacy questions are entailed by prior questions regarding the desirability of generalizing the somewhat dyadic model of secessionist dispute management that is symbolized by the Quebec case (as opposed to the much more triadic model that is symbolized by the Katanga case). ${ }^{9}$ A concomitant question is the extent to which other countries that are faced with similar secessionist claims ought to adopt the model of secessionist dispute resolution that is symbolized by the Quebec case (as opposed to the model that is symbolized by the Katanga case)? For, if the credibility and legitimacy of a model of secessionist dispute management is crucial to its eventual effectiveness, then the more serious the legitimacy deficits that afflict a model of secessionist dispute management, the less likely it is to perform effectively in the long run. And if the legitimacy deficits that afflict one of these models of secessionist dispute management are significantly more serious than those that afflict the other, it should follow logically that the less problematic model (from the legitimacy

Like virtually every other scholar, Peter Hogg, who is widely regarded as Canada's foremost constitutional scholar, clearly regards the court as an integral arm of Canada's federal government. See P.W. Hogg, Constitutional Law of Canada, student edn. (Scarborough, Ontario: Carswell, 2000) at pp. 201-202; 221-245.

The high stakes political nature of this matter is widely acknowledged in the literature. For instance, in the Quebec Case, the Attorney-General of Canada noted in her factum that: 'The Government of Quebec and of Canada are in disagreement over a process so serious that it could lead to the secession of Quebec'. See A. Bayefsky, Self-determination in International Law: Quebec and Lessons Learned (The Hague: Kluwer Law International, 2000) at 13.

9 The concepts of dyadic and triadic models of dispute management are explained more fully in section III of this paper. 
perspective) ought to be preferred to the more problematic one. It also follows that the more problematic model ought not be adopted too hastily in other places (especially in very deeply fragmented societies: where the very question of the legitimacy of state institutions is all-too-often a central concern among aggrieved sub-state groups).

Much of this paper is devoted to critically examining the alternative models of dispute management that are symbolized by the Katanga and Quebec cases. This is done with a view to evaluating the desirability of each of these models as general frameworks that might guide those concerned to manage secessionist disputes between states and sub-state groups. The central concern will be the extent to which either model satisfies what most people in most places seem to regard as basic requirements of procedural fairness, and the extent to which a failure in that regard is likely to affect the legitimacy of the processes and outcomes that follow from that model. The assumption is of course that the perceived fairness of a process and an outcome are intricately connected to their perceived legitimacy. ${ }^{10}$ This critical interrogation of the structures of adjudication that are symbolized by the instant cases is not based on a mere formalist quibble. Indeed, this enterprise seems both necessary and worthwhile precisely because it is the perceived unfairness and illegitimacy of the structures, workings and decisions of state institutions and processes that is all-too-often at the root of secessionist agitations, ethnic conflicts, social dislocations, and global instabilities. ${ }^{11}$ Thus, the set of questions to be addressed under this 'legitimacy' rubric is of utmost relevance to the peaceable management of the secessionist ambitions of a large number of ethnic and national minorities/groups the world over. ${ }^{12}$ They are therefore relevant as well to the sustained maintenance of international peace.

But before delving into that aspect of the paper, it is necessary to examine another crucial set of issues that is raised by the decisions in the Katanga and

10 See T.M. Franck, Fairness in International Law and Institutions (New York: Oxford University Press, 1995) at 25-41. See also O.C. Okafor, "Is there a Legitimacy Deficit in International Law and Institutions' (1997) 13 (Special Issue) International Insights 91 at 96-97.

11 See I.S. Shivji, 'The Right of Pcoples to Self-Determination: An African Perspective' in W. Twining (ed.), Issues of Self-Determination (Aberdeen: Aberdeen University Press, 1991) at 35-37; V.P. Nanda, infra note 18 at 265; H. Hannum, Infra note 18 at 8-9 and 469; and N. Berman, 'Sovereignty in Abeyance: Self-Determination and International Law' (1988) 7 Wisconsin International Law Journal 51 at 53 .

12 See M. Mutua, 'Why Redraw the Map of Africa: A Moral and Legal Inquiry' (1995) 16 Michigan Journal of International Law 1113. See also O.C. Okafor, Re-Defining Legitimate Statehood: International Law and State Fragmentation in Africa (The Hague: Martinus Nijhoff, 2000); and O.C. Okafor, "After Martyrdom: International Law, Sub-State Groups, and the Construction of Legitimate Statehood in Africa' (2000) 41 Harvard International Law Journal 503. For the relevance of this question to the minority populations of a country that is widely viewed as one of the most developed in the world, see M.D. Walters, 'Nationalism and the Pathology of Legal Systems: Considering the Quebec Secession Reference and its Lessons for the United Kingdom' (1999) 62 Modern Law Review 371 at 372 (pointing out the interest with which secession is regarded by many in Scotland, Wales and Northern Ireland - all parts of the United Kingdom). 
Quebec cases: the highly controversial question of the contemporary existence, albeit in a highly limited form, of an international legal entitlement to secede; one that may be considered and pronounced upon by a judicial or quasi-judicial tribunal. A related question relates to the existence as part of African regional international law of a limited, treaty-based (as opposed to custom-based), entitlement to secede from an already de-colonized state. Another related question concerns the possible affirmation in the Supreme Court's decision of a multilateral (as opposed to a unilateral) international legal entitlement to secession; an entitlement that seems to have a novel and useful aspect. It is important that these questions be examined at this point in the paper for the reason that it is only in the context of the existence of such an international legal entitlement that a serious discussion of the legitimacy deficits of each of the two alternative models of secessionist dispute management is sensible. Why quibble about the structure of a formal adjudicative process in the absence of an entitlement that the process might in fact be able to adjudicate?

Thus, the paper is organized as follows. Section 2 critically (but briefly) examines the question of the contribution of the Quebec and Katanga Cases to the clarification of the international law of secession, an area of international law that is to this day steeped in far too much disagreement. ${ }^{13}$ Section 3 critically examines (from a legitimacy perspective) the two alternative models of secessionist dispute management that are symbolized by the Quebec and Katanga cases, respectively. It inquires the extent to which either model represents a significant departure from popularly accepted, widely established, and clearly imperative understandings of fair process, and the extent to which such a deviation (if any) might detract from the legitimacy (as opposed to the legality) of that model. As an integral part of this analysis, it also examines the capacity of either model to advance or inhibit the causes of oppressed minority groups the world over. Following this analytical inquiry, the article concludes with a summary of the questions raised and the suggestions made in each respect. $^{14}$

13 See J. Oloka-Onyango, 'Heretical Reflections on the Right to Self-Determination: Prospects and Problems for a Democratic Global Future in the New Millenium' (1999) 15 American University International Law Review 151 at 196-204.

14 It is extremely important, at this juncture, to delimit the scope of this paper. It is important to understand that due to space limitations, primarily, the paper is not concerned with a number of related and otherwise important issues. These include: the relationship between the two models of secessionist dispute management and the likelihood that states might recognize the statehood of a sub-state group that has seceded successfully from its parent state; the existence of a custom-based secessionist entitlement under international law; the philosophical and other arguments for or against the existence of a right to secession; and the question whether Quebec is or is not entitled to secede. Rather, the paper is limited to a consideration of the existence of a secessionist entitlement that is based on certain treaty and soft-law instruments, especially those considered in the Katanga and Quebec cases, as well as a discussion of the legitimacy questions that arise from the nature of each of the two models of secessionist dispute resolution that are symbolized respectively by the two cases. 


\section{Secession: An Emergent International Legal Entitlement?}

This section begins by discussing, albeit in summary form, the traditional position of international law regarding the entitlement of sub-state groups to secede from already independent states. Next, it examines the nature of international law's attitude to the question of the existence of a secessionist entitlement post the Katanga and Quebec cases. As an intricate part of that more extensive examination, it muses on the implications of the current international legal position in this area for the advancement of the status of oppressed or powerless minority groups.

It is well accepted among scholars that traditional international law was, for the most part, insensitive to the separatist demands of sub-state groups. ${ }^{15}$ As such, that normative order was widely viewed as concomitantly resistant to the emergence of a secessionist entitlement. ${ }^{16}$ As Antonio Cassese has suggested, international law has (historically) been:

' $[b]$ lind to the demands of ethnic groups, and national, religious, cultural, or linguistic minorities. Not only does international law refrain from granting any right of internal or external self-determination to these groups, it also fails to provide any alternative remedy to the present plight of so many of them. ${ }^{, 17}$

This attitude of the law has been widely recognized by, and reflected in, the relevant scholarly literature. ${ }^{18}$ As Joe Oloka-Onyango has recently noted:

'Traditional international law theorists have a deeply ingrained aversion to contemplating the right to secede even in the abstract. Few are willing to infer that the right to secession even exists at all, and suggestions to the contrary immediately draw a retraction. ${ }^{19}$

15 See G.H. Fox, 'Self-Determination in the Post-Cold War Era: A New Internal Focus' (1995) 16 Michigan Journal of International Law 733 at 736.

16 See A. Cassese, Self-Determination of Peoples: A Legal Reappraisal (Cambridge: Cambridge University Press, 1995) at 273-359. This kind of resistance is also present in non-legal discourse. See W. Kymlicka, 'Federalism and Secession: At Home and Abroad' (2000) 13 Canadian Journal of Law and Jurisprudence 207.

17 A. Cassese, ibid. at 328 .

18 See for instance H. Hannum, Autonomy, Sovereignty, and Self-Determination: The Accomodation of Conflicting Rights (Philadelphia: University of Pennsylvania Press, 1990) at 49; V.P. Nanda, 'Self-Determination Under International Law: Validity of Claims to Secede' (1981) 13 Case Western Reserve Journal of International Law 257 at 263-279; and L.-C. Chen, 'Self-Determination and World Public Order' (1991) 66 Notre Dame Law Review 1287 at 1294-1297.

19 See J. Oloka-Onyango, supra note 13 at 198-199. An example of this position is C. Gans, 'National Self-Determination: A Sub and Inter-Statist Conception' (2000) 13 Canadian Journal of Law and Jurisprudence 185. Given the fact that secessionist agitations have continued to occur the world over despite the reluctance of traditional international law scholarship and practice to contemplate the emergence of a broad right of secession, it seems rather curious that this traditional attitude continues nevertheless to dominate current thinking in this area. See D.M. Weinstock, 'Toward a Proceduralist Theory of Secession' (2000) 13 Canadian Journal of Law and Jurisprudence 251 at 161. 
Scholars are, however, now unanimous in their agreement that contemporary international law recognizes the right of colonized peoples to elect to secede from the political control of their colonial masters. ${ }^{20}$ Ian Brownlie, a widely respected scholar, has even suggested that this anti-colonial norm may have attained the rank of a peremptory norm of general international law from which no derogation is permissible (i.e. jus cogens) ${ }^{21}$ an assertion to which Frederic Kirgis, another important scholar, has given qualified approval. ${ }^{22}$

What is still an extremely controversial issue is the existence of an international legal right entitling a people to secede from the already decolonized state that they currently inhabit: i.e. a legal entitlement to secede in a non-colonial context. Most scholars have suggested that no such international legal entitlement exists. For instance, Hurst Hannum is of the view that constant state practice and the weight of authority require the conclusion that the right of a non-colonial people to secede does not yet exist in international law (a separate question from its desirability). ${ }^{23}$ Similarly, prominent scholars such as Antonio Cassese and Thomas Franck have suggested that international law neither allows nor denies this entitlement to sub-state groups. ${ }^{24}$ Yet, a number of scholars (including many who deny that there is an international legal right to secession) have affirmed, however, that the right to selfdetermination (which might ground the right to secession) extends in some other forms to the non-colonial context. ${ }^{25}$ Thus, because there is already enough widespread agreement that the right to self-determination is not limited to the colonial context, it is now clear that sub-state groups are entitled to exercise the right to self-determination in one form or another. What remains

20 See A. Cassese, supra note 16 at 133-140; L-C Chen, supra note 18 at 1294.

21 See I. Brownlie, Principles of Public International Law (Oxford: Clarendon, 1990) at 513.

22 See F. Kirgis, 'The Degrees of Self-Determination in the United Nations Era' (1994) 88 American Journal of International Law 304 at 305.

23 See H. Hannum, supra note 18 at 49.

24 See T.M. Franck, 'Post-Modern Tribalism and the Right to Secession' in C. Brolman, R. Lefeber, and M. Zieck (eds.), Peoples and Minorities in International Law (Dordrecht: Martinus Nijhoff, 1993) at 12-13; C. Tomuschat, 'Self-Determination in a Post-Colonial World' in C. Tomuschat (ed.), Modern Law of Self-Determination (Dordrecht: Martinus Nijhoff, 1993) at 7; J. Dugard, 'Secession: Is the Case of Yugoslavia a Precedent for Africa?' (1992) 5 African Journal of International and Comparative Law 163 at 165; and H. Hannum, 'Re-Thinking Self-Determination' (1993) 34 Virginia Journal of International Law 1.

25 See for instance R. McCorquodale, 'Self-Determination Beyond the Colonial Context and its Potential Impact on Africa' (1992) 4 African Journal of International and Comparative Law 592 at 593 ; R. McCorquordale, 'Self-Determination: A Human Rights Approach' (1994) 43 International and Comparative Law Quarterly 857 at 860-861; G.H. Tesfagiorgis, 'Self-Determination: Its Evolution and Practice by the United Nations and its Application to the case of Eritrea' (1987) 6 Wisconsin International Law Journal 75; M.G.K. Nayar, 'Self-Determination Beyond the Colonial Context: Biafra in Retrospect' (1975) 10 Texas International Law Journal 321 at 337; M. Haile, 'Legality of Secessions: The Case of Eritrea' (1994) 8 Emory International Law Review 479 at 488-536; T.M. Franck, supra note 10 at 11 . 
hotly disputed is whether that entitlement to non-colonial self-determination extends to the right to secede from an already independent state.

It is against this discursive background that, at the very least since the decisions in the Katanga and Quebec cases, it is no longer prudent to argue with confidence against the existence in some highly limited form of an international legal entitlement to secede (in exceptional cases) from an already de-colonized state; an entitlement that judicial/quasi-judicial institutions may consider and pronounce on. In the same vein, this paper argues that even more compelling is the fact that the decision in the Katanga case has left very little room for reasonable doubt as to the existence, as part of African regional international law of a treaty-based, conditional, and limited entitlement to secession. If this suggestion is correct, then it would be fair to suggest that traditional understandings of this area of the law must now give way to readings of the subject-matter that are more closely reflective of a contemporary audit of the decisions of relevant international law decision-
making fora.

Although Stephen Toope questions the existence of the right of secession, ' $\mathrm{m}] \mathrm{y}$ point is not that a broad customary norm allowing unilateral secession
now exists; that point is dubious at best', 26 the current article advances to the
question of the burden of prof. As both the question of the burden of proof. As both the Katanga and the Quebec cases show, several treaty and soft law-based provisions allow that right (albeit in a limited form), and that especially in the light of the decision in the Katanga case, a very heavy burden must lie on a scholar who insists on offering a different interpretation of the relevant treaty-provisions than those offered in the relevant decisions. This is so since such decisions have proceeded from tribunals that have up to now been widely accepted as authoritative. That burden, dischargeable as it is, is highly onerous nevertheless. This will become the two cases.

In the Quebec case, after affirming that the right of a colonized sub-state group to choose independence from the group's colonizer 'is now
undisputed, ${ }^{27}$ the Supreme Court went much further to hold that:

'In summary, the international law right to self-determination only generates, at best, a right to external self-determination [secession] ... where a people are oppressed, as for example under foreign military occupation; or where a definable group is denied meaningful access to government to pursue their political, economic, social and cultural

\footnotetext{
26 See S. Toope, infra note 29 at 524 .

27 Supra note 6 at 285.
} 
development ... Such exceptional circumstances are manifestly inapplicable to Quebec under existing conditions. ${ }^{, 28}$ (emphasis added)

Inherent in the court's reasoning is a cautious affirmation (based mostly on the examination of international law treaties, soft law instruments, and the writing of some prominent scholars) ${ }^{29}$ of the existence, in highly exceptional cases, of an international legal entitlement to unilateral secession; one that may be claimed by a sub-state group in a suit at law and adjudicated upon by a judicial or quasi-judicial tribunal. Indeed, by explicitly considering the facts relating to Quebec's socio-political and economic status within Canada, and finding that Quebec was so well treated by Canada that it did not meet the extremely high threshold that must be met before a sub-state group becomes entitled (as of right) to secede from an already independent state, the court was signalling clearly that the limited entitlement to secede was of a legal nature (whatever that might mean), and was capable of being considered and pronounced upon by a judicial/quasi-judicial body. The legal nature of this limited secessionist entitlement was affirmed by the court notwithstanding the fact that the court had (as it was fully entitled to ${ }^{30}$ considered the case under its advisory jurisdiction, as opposed to its more usual adjudicatory jurisdiction. ${ }^{31}$ Indeed, the court went to great lengths to fend off a challenge to its assumption of jurisdiction in this case: a challenge that was based on the supposed nonjusticiability of the question of Quebec's entitlement to unilateral secession from Canada! ${ }^{32} \mathrm{I}$ am therefore in agreement with Mark Walters that with respect to the Quebec case, all is said and done:

' $[t]$ he nine supreme court justices ruled unanimously that ... Canada [an independent state] is divisible and (by implication) destructible, and that there are legal rules governing such a division. ${ }^{33}$ (emphasis added)

\section{$28 \quad$ Ibid. at 287.}

29 See S. Toope, 'Re Reference by Governor in Council Concerning Certain Questions Relating to Secession of Quebec from Canada' (1999) 93 American Journal of International Law 519 at 524. Emphasis supplied. I agree with Stephen Toope that the given its inattention to customary international law, the court's methodology is somewhat suspect. But Toope's main argument is largely that the court lost the opportunity to examine the veracity of assertions in the literature of the existence of several types of circumstances under which customary international law would recognize a right to secession. This is an argument for completeness, a case for why the court ought to have considered more scenarios than it did. This is an argument that the court could have affirmed or rejected a more expansive right to secession. It is not, however, an attack on the specific forms of the entitlement to secession that the court affirmed. See S. Toope, Ibid. at 524.

30 A well-known constitutional scholar, Patrick Monahan, has described the court's reference jurisdiction in this case as 'unassailable'. See P. Monahan, 'The Public Policy Role of the Supreme Court of Canada in the Secession Reference' (1999-2000) 11 National Journal of Constitutional Law 65 at 69.

31 Supra note 6 at $227-235$.

32 Ibid. at 25-239.

33 See M.D. Walters, supra note 12 at 371. 
Considering the nature of the textual provisions on which the court's decisions in the area of international law were largely based, it is extremely difficult to assail either the court's reasoning or its conclusions. Article 1 common to the two UN human rights covenants ${ }^{34}$ provides a right to self-determination that many authors see no good reason to limit to the colonial context. ${ }^{35}$ Indeed, there is nothing in the plain words of these provisions that suggests that they do not authorize secession in the kinds of highly exceptional cases in which the court would allow it. Those interpretations of these provisions that regard them as not permitting secession except in the colonial context are based largely on attempts to decipher the customary international law relative to the secession of sub-state groups. But since it is quite possible for a treaty to permit a course of conduct that is not as yet permitted by customary international law, it is difficult to see why our understanding of the plain and non-circumscribed words of these provisions should be limited so fundamentally by the presumed absence of a custom-based secessionist entitlement. The traditional view is even more intriguing given the conclusion of a number of eminent scholars that contemporary customary international law neither authorizes nor prohibits secession. This is a position that would clearly allow for an interpretation of these treaty provisions that remains consistent with paragraph five of the relevant section of the Declaration on Friendly Relations, i.e. Resolution 2645 (XV). This is the position that the Supreme Court has (quite correctly in my view) adopted.

Interestingly enough, in addition to affirming the right to unilateral secession in three highly exceptional circumstances, the court also recognized another kind of secessionist entitlement: the right to pursue secession in a multilateral way, i.e. through negotiations with other relevant entities in the relevant state. As enunciated by the court, this is a general legal right that is available both to sub-state groups who do not find themselves in the three situations covered by the entitlement to unilateral secession, and those who find themselves in those situations. So notwithstanding that a sub-state group is not colonized, or oppressed, or denied meaningful access to the governance of their current country, they may still, like Quebec, elect to pursue secession through negotiations. And as along as the other units within that country agree, such a sub-state group should be able to secede from a parent state. This reasoning seems unassailable. Has it not always been within the legal (or meta-legal) rights of a sub-state group to negotiate its exit from an independent state? Examples of such peaceful and consensual dissolutions are not at all hard to find. ${ }^{36}$ In this sense this line of reasoning is not really novel at all. Perhaps its major innovation is that under the court's scheme for the occurrence of such multilateral negotiations regarding secession, when faced with a clear decision

34 See, e.g., Article 1 of the International Covenant on Civil and Political Rights, infra note 79.

35 See T.M. Franck, supra note 10.

36 See L.C. Buchheit, infra note 58 
in favour of secession made by the membership of the relevant sub-state group, the central government is legally obligated to negotiate in good faith with the secessionist sub-state group. In such a case, the central government cannot simply refuse to negotiate secession. Also, it cannot, as was once fashionable, simply deploy violence to crush the expressed will of the relevant population: such conduct is no longer likely to be viewed as lawful. This is the innovative component of this additional entitlement to multilateral secession; one that is clearly of benefit to oppressed sub-state groups the world over. One possible objection to the existence of this procedural right to multilateral secession as part of international law is that it was derived from an analysis of Canadian constitution law, and not from international law as such. A reading of the decision makes it clear, however, that the court is of the view that international law does not explicitly prohibit such consensual multilateral secessions. This is apparent from the court's final decision that there was no conflict between international law and Canadian law in the context of the questions put to it in the reference. ${ }^{37}$ It is also implied in the court's restriction of the law's prohibition of certain kinds of secession to the realm of cases of unilateral secession by non-colonized sub-state groups that are neither oppressed nor fundamentally excluded from power.

As will become obvious in the following segments of this section, the legal reasoning of the African Commission in the Katanga case is strikingly similar in spirit, if not always in letter, to the reasoning in the Quebec case.

In the Katanga case, the African Commission was seized of a communication brought by the President of the Katangese Peoples' Congress [in Zaire] requesting the commission to, inter alia, recognize the independence of Katanga and help secure the evacuation of Zaire from Katanga. This communication claimed that Zaire, a state party to the African Charter on Human and Peoples' Rights ${ }^{38}$ had violated Article 20 of that Charter. Among other things, that provision, guarantees the right to self-determination to both 'colonized and oppressed peoples' in Africa. Having declared the communication admissible, and having considered its claims, the African Commission held that:

'In the absence of concrete evidence of violations of human rights to the point that the territorial integrity of Zaire should be called into question and in the absence of evidence that the people of Katanga are denied the right to participate in government as guaranteed by Article 13(1) of the African Charter, the Commission holds the view that Katanga is obliged to exercise a variant of self-determination that is compatible with the sovereignty and territorial integrity of Zaire. ${ }^{, 39}$ 
One thing that is striking about this decision is the extent to which its legal reasoning was, in effect, endorsed in the admittedly much more extensive judgement of the Supreme Court in the Quebec case. Just like the court in the Quebec case, the African Commission denied that the relevant claimant (Katanga in this case) was, in this specific circumstance, entitled to secede from the already independent state of which they were a part (i.e. Zaire). Just like the court in the Quebec case, the African Commission took it for granted that every colonized people possess the international legal right to secede, should they so choose, from the relevant colonial state. Just like the court in the Quebec case, the African Commission affirmed the existence, in two noncolonial contexts, of a limited international legal entitlement to secede: i.e. in the case of an oppressed people ('serious human rights violations'), and in the case of a people who have been denied meaningful participation in the governance of their country ('denial of Article 13(1) rights'). Just like the court in the Quebec case, the African Commission understood this entitlement as one upon which a quasi-judicial body such as itself is entitled to adjudicate. Like the court in the Quebec case, the African Commission unanimously held in favour of a limited form of the secessionist entitlement, one that is available only in highly exceptional circumstances.

Up to this point, the legal reasoning that grounds the decisions in the two cases are largely ad idem. One difference, however, is that unlike the court in the Quebec case which was clearly engaged in the interpretation of the global international legal position on the issues, the African Commission's task was much more geographically limited. It was engaged in the interpretation of the provisions of the African Charter on Human and Peoples' Rights (a widely ratified 1981 treaty that is inapplicable beyond the African continent). Another significant difference between the two cases is that the African Commission did not have the opportunity to delve into the question of the existence or otherwise of a right to pursue secession in a multilateral manner (i.e. via political negotiations). At the same time though, there is nothing in the instant decision that indicates that the African Commission would have viewed such a right with disfavour. Yet another difference is that while the court in the Quebec case was a domestic judicial body with binding legal authority, the African Commission is an international quasi-judicial body with no binding legal authority as such. ${ }^{40}$ In the present context, however, such a distinction is without any real significance. Was not the Supreme Court acting in its advisory role in the Quebec case? Was that role not functionally similar to that usually performed by the African Commission? In any case, at the moment, the

40 See Article 53 of the African Charter. See also U.O. Umozurike, The African Charter on Human and Peoples' Rights (The Hague: Martinus Nijhoff, 1997); A.C. Odinkalu, 'The Individual Complaints Procedures of the African Commission on Human and Peoples' Rights: A Preliminary Assessment' (1998) Transnational Law and Contemporary Problems, 359 at 405. 
African Commission remains the only functional institution that the African Charter has itself charged with the authoritative interpretation of the provisions of that document. ${ }^{41}$ All in all, it is very clear (from the italicized part of the decision that has been reproduced above) that had the Katangese Peoples' Congress introduced the kind of evidence that met the threshold that was stated by the Commission, it would have (at least in the view of the Commission) been legally entitled to secede from Zaire. That is a logical deduction that is potentially very significant, not just in the African context, but in the rest of the world as well.

In order to understand more fully the huge significance of this decision, especially for most states and sub-state groups in Africa, a number of matters have to be kept in mind. The first is the extreme disfavour with which secession has been viewed historically among the vast majority of African states. ${ }^{42}$ The second is the concomitant historical insistence of most African governments on both the absolute application of the doctrine of uti possidetis and the maintenance of the territorial integrity of decolonized African states. ${ }^{43}$ These two doctrines are so well established that, quite understandably, even this extremely forward-looking African Commission still felt obliged to indicate, in their decision, a considerable measure of respect for them. The third is the considerable extent and weight of the negative interpretive opinion that existed in the period before and after this decision was issued. The first two factors are so widely acknowledged as factual that this paper will concentrate on demonstrating the last one only.

As recently as 1999, Joe Oloka-Onyango, a well-respected African scholar who has himself argued strongly in favour of the creation of a more general right to secession, felt able to dismiss as mere 'wishful thinking' the assertion by another scholar that general international law already recognizes a limited right to secession. ${ }^{44}$ Yet, the decision in the Katanga case was published in 1996. While Oloka-Onyango was on surer ground when he concluded that global international law (as opposed to African regional international law) does not as yet recognize a broad right of secession, he cannot be right if he meant to conclude as well that no limited form of the secessionist entitlement had at

41 The other relevant tribunal, the African Court on Human and Peoples' Rights, is non-functional as yet. See Protocol to the African Charter on Human and Peoples' Rights on the Establishment of an African Court on Human and Peoples' Rights, 10 June 1998 (2000) 12 African Journal of International and Comparative Law 187.

42 See M. Mutua, 'Why Re-Draw the Map of Africa: A Moral and Legal Inquiry' (1995) 16 Michigan Journal of International Law 1113 at 1119.

43 See J.A. Frowein, 'Self-Determination as a Limit to Obligations Under International Law' in C. Tomuschat (ed.,) supra note 24 at 213-215. See also J. Klabbers and R. Lefeber 'Africa: Lost Between Self-Determination and Uti Possidetis' in C. Brolman, R. Lefeber and M, Zieck (eds.), supra note 24 at $37-41$.

See J. Oloka-Onyango, supra note 13 at 199. 
the relevant time been recognized by either general or African international law. Isaa Shivji, another one of the many important scholars who have advocated the creation of a general right to secession, is of the view that the Article 20 of the African Charter, the very same provision that was invoked, considered, and interpreted in the Katanga case, does not guarantee a right to secession in the non-colonial context. ${ }^{45}$ Richard Gittleman even predicted (rather incorrectly as it turns out) that secessionist movements or peoples would not, in furtherance of their causes, be entitled to rely on the right to selfdetermination enshrined in the same Article 20 of the African Charter. ${ }^{46}$ Richard Kiwanuka, Gino Naldi, and Emmanuel Bello came to similar conclusions regarding the meaning and applicability of the very same provision. ${ }^{47}$ Perhaps the only notable exceptions to this steady drum of scholarly opinion regarding the intent of Article 20 are the opinions of $\mathrm{Oji}$ Umozurike (a long-serving member of the African Commission) and Angela Lloyd. Both have suggested that Article 20 of the African Charter clearly guarantees a treaty-based right of secession, one that may in exceptional cases be claimed by a secessionist sub-state group. Both commentators have based their conclusions on what they see as the very plain language of the provision. ${ }^{48}$ Indeed, Umozurike has made the extremely crucial distinction between colonized and oppressed peoples. A people who are not colonized may still be oppressed in other ways! Is colonization not merely one specific kind of oppression? Indeed in Umozurike's own words:

'OAU member states [i.e. African states] have no colonized people in their territories but some have oppressed people; both types of victims are entitled to free themselves by resorting to appropriate means. ${ }^{, 49}$ (emphasis added)

It is therefore clear that Article 20 of the African Charter guarantees a form of self-determination that may in some exceptional circumstances entitle a noncolonized people like the Katangese to secede from an already independent state such as Zaire. This entitlement is a part only of the treaty-based regional international law applicable in Africa. Its content is, however, virtually on all

45 See I.G. Shivji, supra note 11 at 40 .

46 See R. Gittleman, 'The African Charter on Human and Peoples' Rights: A Legal Analysis' (1982) 22 Virginia Journal of International Law 667 at 679.

47 See R. Kiwanuka, "The Meaning of "People" in the African Charter on Human and Peoples' Rights' (1988) 82 American Journal of International Law 80 at 88-90; G. Naldi, 'The Case Concerning the Frontier Dispute (Burkina Faso/Republic of Mali): Uti Possidetis in an African Perspective' (1987) 36 International and Comparative Law Quarterly 893 at 900; and E. Bello, 'The African Charter on Human and Peoples' Rights: A Legal Analysis' (1985-V) 194 Recueil des Cours 13 at 169.

48 See U.O. Umozurike, The African Charter on Human and Peoples' Rights (The Hague: Martinus Nijhoff, 1997) at 53-54; and A. Lloyd, 'The Southern Sudan: A Compelling Case for Secession' (1994) 32 Columbia Journal of Transnational Law 419 at 430.

$49 \quad$ Ibid. at 54. 
fours with the limited entitlement to secession that was affirmed by the Supreme Court in the Quebec case. ${ }^{50}$ This is the chief similarity between the legal reasoning of both the Supreme Court and the African Commission.

In both of these generally salutary cases, the long-term interests of states as well as of minority and/or powerless sub-state groups are well served. A colonized people are clearly recognized as repositories of a 'secessionist' entitlement. Minority and/or powerless sub-state groups, that are either seriously oppressed or fundamentally excluded over time from meaningful participation in the governance of their own country, will have a legal entitlement to secede from the relevant oppressive state. And this is an entitlement that may be considered and adjudicated by a judicial or quasijudicial tribunal institution. This legal state of affairs will encourage such minorities to seek redress for their grievances through more peaceable ways: rather than simply resorting to defensive violence against an oppressive state, such minorities will have a more credible alternative to violent action than a stoic acceptance of their fate as a victimized group. This legal state of affairs will thus remove a very important source of frustration for such aggrieved groups: namely, the absence of credible fora for the peaceable and focused consideration of their claim to secede; fora that are not dominated and controlled by the relevant state. ${ }^{51}$ For their own part, states will be reminded, in a very clear way, that they pursue policies of colonization, excessive political centralization, homogenization, exclusion, and repression, at their peril. ${ }^{52}$ This legal state of affairs will also demand that if states are determined to maintain their territorial integrity, they must be equally determined to refrain from treating any of their sub-state groups in a way that would concomitantly entitle that group to secede from the relevant state! In any case, where a sub-state group has been severely mistreated, 'territorial integrity is self-defeating' for the state itself. ${ }^{53}$ This is so because, when the population of a state remains deeply cleaved, including psychologically, as it usually becomes in such cases, the relevant state's territory may remain physically contiguous without being 'integral' in any real way. ${ }^{54}$

Having made this point, it is also important to note that neither the Katanga case nor the Quebec case supports a broad right of secession in every conceivable circumstance for every aggrieved sub-state group. What both cases suggest is the existence of a highly circumscribed entitlement. The two

so For a brief reference to the similarity of the two decisions, see C. Drew, "The East Timor Popular Consultation: Self-Determination Denied' (1999) 4 Human Rights Law Review 2 at 4.

51 See B. Kingsbury, 'Claims by Non-State Groups in International Law' (1992) 25 Cornell International Law Journal 481.

52 See M.S. Carter, 'Ethnic Minority Groups and Self-Determination: The Case of the Basques' (1986) 20 Columbia Journal of Law and Social Problems 55 at 56.

53 See L.-C. Chen, supra note 18 at 1297.

54 Ibid. 
tribunals were extremely conscious of the fact that, as Oji Umozurike has reminded us, most responsible scholars accept the idea that 'the independence variant of self-determination will not be lightly entertained in the absence of compelling circumstances'. ${ }^{55}$ Indeed, there are compelling social reasons for the endorsement of this kind of measured approach to adjudication of the secessionist entitlement. As Rein Mullerson has noted:

'Human suffering in inter-ethnic conflicts following some recent cases of secession should induce every responsible person to think twice before speaking in favour of any secession. 56

It must be kept in mind, however, that it is not always that assertions of the right to secession result in violent conflict. The separation of the Czechs and the Slovaks was done by 'mutual assent'. ${ }^{57}$ So was the secession of Singapore from Malaysia in $1965 .^{58}$ Assertions of the right to secession by Quebec has, for the most part, not led to violent conflict in Canada. ${ }^{59}$ Furthermore, as Mullerson has himself noted, 'the violence we see around us is not generated by the drive for self-determination, but by its negation [by the activities of oppressive states] ${ }^{60}$ Thus, were states to adopt a less bellicose posture to the autonomy claims of sub-state groups, and not rush to violently suppress the slightest indication of separatism, violence would hardly attend most attempts to vindicate such claims. Indeed, part of the reason for the penchant of states to violently suppress secessionist sub-state groups is that they think that they can do so within the law: they believe that secession is absolutely illegal under international law, and that the law entitles independent states to deploy violence in order to suppress any conduct that they perceive as demonstrative of an attempt by a sub-state group to secede. ${ }^{61}$

The foregoing paragraphs have demonstrated the basis for my suggestion that the Katanga and Quebec cases point in the direction of the emergence of a number of highly circumscribed treaty(and soft-law)-based entitlements to secession (as opposed to a broad customary international law norm in favour of secession); rights that are often claimed by sub-state groups and denied by

55 See U.O. Umozurike, supra note 40 at 53.

56 See R. Mullerson, International Law, Rights and Politics (London: Routledge, 1994) at 85.

57 See S. Massa, 'Secession by Mutual Assent: A Comparative Analysis of the Dissolution of Czechoslovakia and the Secessionist Movement in Canada' (1995) 14 Wisconsin International Law Journal 183 at 184.

58 See L.C. Buchheit, Secession: The Legitimacy of Self-Determination (New Haven: Yale University Press, 1978) at 97-221.

59 The only exception to the generally peaceful atmosphere that has characterized the struggle over Quebec's possible secession from Canada is the FLQ crisis of the 1970s. See L. Fournier, infra note 104 .

60 Ibid

${ }^{61}$ This is a point that I have demonstrated at length in another forum. See O.C. Okafor, Re-Defining Legitimate Statehood, supra note 12 at 92-125. 
states. Having done so, and since disputed entitlements must be adjudicated according to one kind of process or the other, the stage is set for an analytical examination, in the next section, of the contrasting models of secessionist dispute management processes that are symbolized by the Katanga and Quebec cases. This examination will be conducted with a view to assessing the legitimacy deficits, if any, that afflict these models, while musing on the desirability of both models as general frameworks for the management of secessionist disputes.

\section{Secession: Re-Conceiving Process, Enhancing Legitimacy?}

This section of the paper will, first of all, consider the nature of one of the basic requirements of fair process. Next, it will examine briefly the incorporation, into some of the world's legal systems, of that requirement of fair process. Following that discussion, it will relate the relevant requirement of fair process to the question of the perceived legitimacy of either of the alternative models of secessionist dispute management that are symbolized by the Katanga and Quebec cases. The central concern that will animate this discussion will be the extent to which a process of secessionist dispute management that is based on either model is more likely to be viewed as fair and/or legitimate (especially by the losing side)? Intricately connected to this legitimacy question are the musings as to the capacity of these models to better advance the causes of oppressed or powerless sub-state groups the world over.

It is generally accepted, virtually everywhere in the world, that disputes are more likely to be resolved in a way that fosters and sustains the confidence of the parties thereto in the legitimacy of the processes involved, and the outcomes that are entailed, if such disputes are adjudicated, mediated or otherwise managed by a relatively detached and independent third party. ${ }^{62}$ Indeed, Alec Stone Sweet has recently reminded us that:

'The triad - two contracting parties and a dispute resolver - constitutes a primal social institution, a microcosm of governance. ${ }^{63}$

The triadic (i.e. the relatively detached and independent third party) model of dispute management is opposed to the dyadic (i.e. the exclusively inter-party) model. ${ }^{64}$ A good example of dyadic dispute resolution is a situation where two friends simply meet to settle between them and by themselves a dispute over

\footnotetext{
62 That this understanding grounds most principles of fair judicial process the world over is now axiomatic.

63 See A. Stone Sweet, 'Judicialization and the Construction of Governance' (1999) 32 Comparative Political Siudies 147.

64 Ibid. at $148-149$.
} 
a personal loan. In such a case, all of the participants in the dispute management process are disputants as well.

This dyadic model is rendered triadic by the injection of an external presence ${ }^{65}$ in the form of a relatively detached and independent third party dispute 'resolver'. This is the structure of adjudication that is favoured almost exclusively in the management of disputes by judicial and quasi-judicial institutions the world over. ${ }^{66}$ And virtually every serious dispute concerning the legal rights and obligations of the members of virtually every society in the world are now settled in one triadic form or the other. Whether or not these disputes are settled in a court of law, strictly so called, or in an alternative dispute resolution forum, a triadic model of adjudication is usually entailed. This does not mean, however, that dyadic or quasi-dyadic dispute management is not somewhat ubiquitous in most societies. ${ }^{67}$ In any case, when citizens sue the government in a domestic court of law, the model of dispute management that is entailed is not purely or classically triadic. For, are courts of law not part of a state's judiciary? And is the judiciary not one of the three arms of the very government that has been sued? Again, is the judiciary not usually appointed by, or intricately linked to, one or the other of the executive and legislative arms of government? Is the court of law not therefore hard put to claim 'detached third party' status in the classic sense? The point is not that the dyadic model does not at all inform the design of those of our adjudicative structures that have been dedicated to the management of serious legal disputes. The point is that the dyadic model's influence on the design of such adjudicative structures is largely minimal - at least in the sense that, even when the dyadic model appears to have influenced the design of the adjudicative structures, serious attempts are usually made to secure for the relevant adjudicators some measure of relative detachment and independence. And it is hardly debatable that the insistence by so many legal systems on the necessity of these measures reflects a deeply established aspiration to the 'triadic'.

That the triadic model of dispute management is deeply ingrained in the structures and sensibilities of the judicial systems of most countries in the world is evidenced by the virtually universal valency of the concept of nemo judex in causa sua (that no one ought to be a judge in her own cause). In some

65 Ibid. at 149.

66 See R.E. Hudec, 'The Judicialization of GATT Dispute Settlement' in M.H. Hart and D.B. Steger (eds.), In Whose Interest?: Due Process and Transparency in International Trade (Ottawa: Center for Trade Policy and Law, 1992); and R.E. Hudec, Enforcing International Trade Law: The Evolution of the Modern GATT Legal System (Salem, N.H.: Butterworths, 1993).

67 See R.C. Ellikson, Order Without Law: How Neighbours Settle Disputes (Cambridge, MA: Harvard University Press, 1991); and G.M. Foster, 'A Dyadic Contract: A Model for the Social Structure of a Mexican Peasant Village' in S.W. Schmidt, J.C. Scott, L.G. Lande (eds.), Friends, Followers, and Factions (Berkeley: University of California Press, 1977). 
countries this principle is recognized as a principle of 'natural justice', 68 in others, as a requirement of 'fundamental justice'. ${ }^{69}$ It is also recognized both in the letter and the spirit of contemporary international human rights law. Indeed, the principle is now so well established that most ordinary people have come to take it for granted, and expect that it will be respected as a matter of course. This is a principle that is so ingrained in the sensibilities of most people in most places that there is very little room for reasonable doubt as to its stature as an indispensable basic requirement of fair dispute management. In fact, dispute management models that violate its tenets are most likely to be widely regarded as unfair (especially by losing parties). ${ }^{70}$ There is equally very little reasonable doubt that this time-hallowed requirement is firmly etched in the minds of most people in most places as a desideratum for the legitimacy of a dispute management process and of its outcomes. Thus, dispute management models that violate its core tenets are likely to be widely regarded as illegitimate. ${ }^{71}$

In the context of the incorporation of this ethical requirement of fair process by the jurisprudence of virtually every kind of legal system, a survey of even a few sample jurisdictions is enough to show case the nature of this fundamentality of this requirement of 'fairness as legitimacy'. In the case of Nigeria, Phillip Nnaemeka-Agu, a former Justice of the Supreme Court of Nigeria, has had occasion to reflect in extenso on the nature of the legal concept of nemo judex in causa sua (that no person shall be a judge in his or her own cause). ${ }^{72}$ In his view, this is a fundamental pillar of the concept of fair judicial process in both the common law and non-common law worlds. ${ }^{73}$ More generally, the fundamentality of this concept of fairness has recently been emphasized by a diverse group of African scholars in the 1999 Dakar Declaration on the Right to Fair Trial in Africa. ${ }^{74}$ In Fawehinmi v. Legal Practitioners Disciplinary Committee, ${ }^{75}$ this concept of fair judicial process was applied and developed by the Supreme Court of Nigeria as a prohibition against a person or institution sitting in judgement in a context in which either party to the dispute does not, upon reasonable grounds, regard that person or

68 In Nigeria, for instance, this imperative is widely referred to as a principle of 'natural justice'. See P. Nnaemeka-Agu, infra note 72.

69 In Canada, for instance, this imperative is widely referred to as a requirement of 'fundamental justice'. See R.A. McDonald, infra note 76.

70 I use 'unfaimess' in the sense of 'shared perceptions as to what is unconditionally unfair'. See T.M. Franck, Fairness in International Law and Institutions, supra note 10 at 15.

71 I use the term 'illegitimacy' in the sense by Charles Taylor in the passage reproduced at the beginning of this paper. Jean Leclair as also used that term in the same sense. The emphasis is on the expectations of the target audience(s). See J. Leclair, infra note 110 at 2.

72 See P. Nnaemeka-Agu, 'Fair Hearing: The Corner Stone of Our Adjudicative Process' (Enugu: Faculty of Law University of Nigeria, 1989) at 7-22.

73 Ibid. at 14.

74 (2000) 7 International Human Rights Reports 600.

75 (1985) 2 N.W.L.R. 50. 
institution as a detached and impartial arbiter. In the case of Canada, Roderick Macdonald has demonstrated how the kindred concept 'nemo iudex in causa sua debet esse' (let no person be a judge in her or his own cause) has always been a fundamental requirement of fair judicial process in Canada. In his view, this concept of fairness requires that only a person who is capable of being viewed by both parties to a dispute as an 'impartial and disinterested decisionmaker' can lawfully adjudicate such a dispute. ${ }^{76}$ In Britain, Re Pinochet Ugarte $^{77}$ is a recent and powerful reminder of the hallowed place that this requirement of fairness occupies in the minds of both judges and members of the public alike (at least in Britain). In that case, the House of Lords was very publicly embarrassed when it had to set to aside its own earlier decision ${ }^{78}$ concerning the possible extradition to Spain of General Pinochet Ugarte. The court was compelled to so hold owing to the apprehension of bias on the part of one of the judges that had heard the case, namely, Lord Hoffman (i.e. his perceived partiality). This Law Lord had been shown to have very close links with one of the participants in the case before the court, namely, Amnesty International. He was, at least at the relevant time, a director and chair of a charity that was intricately connected to Amnesty International. Futhermore, contemporary international human rights law is most reflective of this same concept of fair adjudicative process. Article 14 of the International Covenant on Civil and Political Rights ${ }^{79}$ provides for a concept of fair trial that entails similar notions of fairness. This right is also enumerated by Article 7 of the African Charter on Human and Peoples' Rights. ${ }^{80}$ Thus, it is clear that the notion of fair adjudication that was suggested above enjoys widespread approval in various parts of (if not throughout) the world. There is very little doubt that dispute management models that violate its requirements are very likely to be widely viewed as unfair and illegitimate (at least by the losing side).

This is not to say, however, that a dyadic model of dispute management will in all cases lead to serious doubts among the target audience regarding the fairness and legitimacy of the judicial process. In fact, in most countries, courts

76

See R.A. Macdonald, 'Procedural Due Process in Canadian Constitutional Law: Natural Justice and Fundamental Justice' (1987) 39 University of Florida Law Review 217 at 235. See also J.M. Evans, 'The Principles of Fundamental Justice: The Constitution and the Common Law' (1991) 29 Osgoode Hall Law Journal 51; D.J. Mullan, 'Natural Justice and Fairness - Substantive as well as Procedural Standards for the Review of Administrative Decision-Making?' (1982) 27 McGill Law Journal 250; Miller v. Canada [1996] F.C.J. No. 735, p. 1 at 5-7; Pearlman v. Manitoba Law Society Judicial Committee [1991 2. S.C.R. 869; and Bruton v. Regina City Policemen's Association, Local 155 [1945] 3 D.L.R. 437.

77 [1998] H.L.J. No. 52.

78 See [1998] H.L.J. No. 41.

7919 December 1966, 6 I.L.M. 368.

8019 January 1981, 21 I.L.M. 59. 
of law appointed by the government of that country routinely manage disputes between that same government and its citizens. Yet there is no evidence that this ubiquitous model of judicial action is widely viewed as inherently unfair and illegitimate. Where questions of unfairness and/or illegitimacy have arisen, they have usually done so because of the performance of specific judges in specific cases, not as a general comment on the very structure of adjudication that is involved. The point though is that this quasi-dyadic model of judicial action (in which an arm of a government adjudicates a dispute between that same government and a citizen) is widely accepted by the public largely because, by ensuring some measure of relative detachment and independence for the courts of law, serious efforts have been made in that situation to aspire to the triadic model. Where such serious efforts have not been made, and the relative detachment and independence of the courts of law are in serious doubt, the very structure of the judicial process is likely to be impugned by the public as unfair and/or illegitimate. Put differently, in countries where, and in eras when, such measures ensuring the detachment and independence of the courts are either not in place or are not widely respected in practice, their judicial systems are all-too-often widely viewed within the relevant populations as unfair, illegitimate, or both. And one of the chief reasons for the likelihood of this popular perception is that in such cases, the structure of adjudication in those courts would, in effect, have leaned too far to the dyadic side of the dyadtriad continuum. The courts, in such cases, would have virtually become the puppets of one or both of the other arms of the government; not the relatively detached independent third parties that citizens, desirous as they are of the triadic model, expect them to be. ${ }^{81}$

Having shown that the quasi-dyadic adjudicative structure (in which an arm of the government adjudicates a dispute between that same government and a citizen) is prevalent, warts and all, the world over, it is still important to note that it is not in every disputative context, that that model would be either suitable or preferable. Indeed, that model is, as will be shown soon, highly unsuitable as a general model for the management of the most highly divisive, high stakes, and political kinds of disputes (such as disagreements regarding secession).

It is only logical to expect that the more controversial, divisive, and high stakes a political dispute is, the more likely it is that the legitimacy of the process by which it is adjudicated would be closely scrutinized. In the context of such close scrutiny of the legitimacy of the process of adjudication, it seems logical to expect that the more detached and independent the process is, the more likely it is to command (as opposed to demand) the imprimatur of popular

81 For instance, see O.N. Ogbu, 'The Judiciary in a Polity - A Force for Stability or Instability?: The Nigerian Experience' (1999) 11 African Journal of International and Comparative Law 724 at 726-735. 
legitimacy. And since the triadic model of dispute management, much more than the dyadic model, better ensures the detachment and independence of the adjudicator(s) (and therefore of the process), the triadic model is much more preferable as a general framework for the management of such highly divisive, high stakes, political disputes (as those concerning secession). In fact, very few of the different genres of political disputes are more high states, divisive, or controversial than disputes concerning the very division (even destruction) of a country via the instrumentality of the successful secession from that country of one of its constituent units! Such disputes concern matters that are at the very foundations of the relevant state itself. Such disputes concern the possibility of authorizing an event of incredibly momentous consequences. Such disputes are most likely to generate a highly charged political atmosphere. Secession and the nationalisms that are entailed are, as history tells us, potentially explosive issues. ${ }^{82}$ Secession is a question that taxes to extremes the emotional strength of all sides of the dispute. ${ }^{83}$

These insights into the nature of secessionist disputes definitely apply to both the broader political disputes that spawned the Katanga and Quebec cases, as well as to the cases themselves. In both of these cases, it was clear that the decision to refer the respective sets of secession questions to the Supreme Court and the African Commission, respectively, was in each case part of broader political strategies designed to advance one side of an extremely high stakes political game. In the Katanga case, the Katangese Peoples' Congress was in search of a pronouncement as to its international legal entitlement to secede that could constitute an important resource in an already existing decades old political and military struggle for the independence of the province of Katanga from Zaire. Thus, the reference of this matter to the African Commission, as well as the decision that was rendered, were both resources that would be harnessed and pressed into the service of the high stakes politics of secessionist agitation in Zaire. This is evident from the nature of the questions posed, and requests made, to the African Commission. For instance, the African Commission was asked to 'recognize the Katangese Peoples' Congress as a liberation movement ${ }^{84}$ This was clearly a well thought out strategy of mobilizing the language and style of the many liberation movements that were successful either in de-colonizing African states or ridding them of apartheid regimes. This appropriation of the term 'liberation movement' was thus important in the context of securing international support (especially in Africa) for the struggle of the Katangese to secede from Zaire.

82 The explosiveness of this issue knows no north-south or west-east boundaries. The situations in Northern Ireland, Bosnia, Kosovo, Ethiopia-Eritrea, Senegal-Casamance, Spain-Basque Region, and Quebec (during the violent FLQ crisis) are more than enough evidence for this assertion.

83 See S. Choudhry and R. Howse, 'Constitutional Theory and the Quebec Secession Reference' (2000) 13 The Canadian Journal of Law and Jurisprudence 143 at 145.

84 See supra note 4 at para. 1. 
In the Quebec case, the reference was clearly a part of the Government of Canada's larger political strategy designed to ensure that it did not lose the next referendum, outlined as it turns out in its so-called 'Plan B'. ${ }^{85}$ This plan was hatched in the wake of the near success of the 1995 Quebec independence referendum. ${ }^{86}$ The gravamen of this plan was to clarify the process of secession and make its costs more obvious to the Quebec electorate. ${ }^{87}$ This was seen as a strategy that would contribute immensely to the anti-secessionist cause of the federal government and detract as immensely from the secessionist cause of the Quebec government. Given Patrick Monahan's description of the Supreme Court as 'a federal political institution', ${ }^{88}$ and his conclusion that (in giving something to each side of the dispute and avoiding all the hard questions, in this case, 'the court may have been acting as politicians rather than as judges ${ }^{89}$ ), it is even clearer that the court was itself quite cognizant of the nature of this case as part and parcel of a broader high stakes political game. That much is implied in its handling of the challenges posed by the amicus curiae to its jurisdiction. ${ }^{90}$ And if this is not sufficient evidence of the inherently charged political nature of this secessionist dispute, and the court's realization of that fact, the subsequent passage by another arm of the Government of Canada of the so-called Clarity Act ${ }^{91}$ (which was clearly designed to narrow the range of political manoeuvres available to Quebec ${ }^{92}$ is proof positive of this assertion. It is thus clear that struggles over the possible secession of a sub-state group from an already independent state do not become less political, less charged, less divisive, or less high stakes, simply because they have been submitted to a quasi-judicial, judicial ${ }^{93}$ or other process.

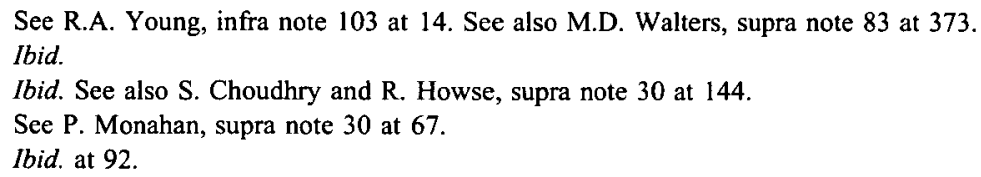

See R.A. Young, infra note 103 at 14. See also M.D. Walters, supra note 83 at 373.

Ibid.

Ibid. See also S. Choudhry and R. Howse, supra note 30 at 144 .

See P. Monahan, supra note 30 at 67.

Ibid. at 92.

Supra at 235-239.

An Act to Give Effect to the Requirement for Clarity as set out in the Opinion of the Supreme Court of Canada in the Quebec Secession Reference, S.C. 2000, c.26. of 18 July 2000.

92 Under this Act's provisions, the Government of Canada has allocated to itself a veto over the decision as what a 'clear question' or 'clear expression of the will of the electorate' means in the context of a referendum on independence in Quebec. Contrast this with Bruce Ryder's insightful commentary on the Quebec case. He reads the Quebec case as requiring that all the relevant actors (not just one of them) should together determine if a particular referendum question is clear or not, or if a particular voting majority is sufficient to authorize the Quebec government to pursue multilateral secession. See B. Ryder, 'A Court in Need and a Friend Indeed: An Analysis of the Amicus Curiae in the Quebec Secession Reference' (1998) 10 Constitutional Forum 9 at 13.

93 On the increasing trend toward the 'judicialization' or 'juridification' of even high stakes political disputes, see C.N. Tate and T. Vallinder, 'The Global Expansion of Judicial Power: The Judicialization of Politics' in C.N. Tate and T. Vallinder (eds.), The Global Expansion of Judicial Power (New York: New York University Press, 1995) at 1-10. See also M.D. Walters, supra note 12 at 390. 
Indeed, the submission of such a claim to a quasi-judicial or judicial process is merely the continuation of high stakes politics by other means.

It is this deeply politicized and high stakes character of most secessionist disputes that best explains the need for such disputes to be adjudicated within a relatively detached and independent third party dispute management forum. That is why the more a secessionist dispute management mechanism tends to be dyadic, the more likely it is to foster perceptions and accusations of inherent/ systemic unfairness and illegitimacy. And that is why the more such a mechanism tends to be triadic, the less likely it is to foster perceptions and accusations of inherent/systemic unfairness and illegitimacy. It is of course possible that given the presence of a particular kind of political psychology among a particular population, even a dyadic mechanism may not in fact foster perceptions and accusations of inherent/systemic unfairness and illegitimacy. But the point is that even in that type of context a triadic mechanism would, with all other factors being equal, be less likely to foster perceptions and accusations of inherent/systemic unfairness and illegitimacy.

In the context of the Quebec and Katanga cases, the question that arises is whether, in the interest of ensuring the perceived legitimacy of the entire process, Quebec and Katanga were entitled to expect fundamental justice in the respective determinations regarding their entitlement to secession that were made by the Supreme Court and the African Commission? Does this expectation of fundamental justice entail an expectation of a triadic form of adjudication? Does fundamental justice require inexorably the adjudication of secession-related matters by a tribunal that is seen by all sides of the dispute to be detached from and independent of one of the parties to the dispute? Does fundamental justice require the adjudication of these kinds of disputes by a third party tribunal that is completely detached and independent of one of the disputants? If so, is this requirement only satisfied when the adjudicative process is conducted within an external or international judicial or quasijudicial tribunal? To be more concrete, is Quebec, for instance, entitled to expect fundamental justice in the assessment of the clarity of say a disputed referendum question related to its secessionist ambitions? Would the process of assessing the clarity of such a question be widely perceived as unfair and/ or illegitimate were it to violate one or more of the basic requirements of fundamental justice? And even if, in the specific socio-political context of Canada, the basic tenets of fundamental justice (and thus the imperative for popular legitimacy) can be said not to require a completely detached and independent external or international institution, would such a more triadic model of adjudication be required by the principles of fundamental justice almost everywhere else in the world?

The central concerns here are chiefly ethical and pragmatic, as opposed to being strictly legalistic. And in order to reflect more clearly on these questions and concerns, it is important that we outline the nature of each of the 
alternative models of secessionist dispute management that are symbolized by the Katanga and Quebec cases.

In the Katanga case, the Katangese Peoples' Association (a sub-state entity) referred a secessionist dispute between itself and its parent state (Zaire) to the African Commission (an international quasi-judicial tribunal operative only in Africa). The African Commission constitutes of persons appointed by an umbrella international institution, the Organization of African Unity (or $\mathrm{OAU}) .{ }^{94}$ And despite the fact that the members of the OAU are all states, and that it is the assembly of the heads of these states that appoint the members of the African Commission, neither the Commission as a corporate whole nor any one of its commissioners can at any one time be said to be functioning as an official of the specific state against which a particular secessionist claim has been brought. The Commission's diversity ensures this, ${ }^{95}$ and its Rules of Procedure support this characterization. ${ }^{96}$ In any case, in this particular case, none of the members of this eleven-person commission was either Katangese or from the rest of Zaire.

In the Quebec case, the Governor-in-Council (one of the arms of the Government of Canada) referred a dispute between the Government of Canada and the Government of Quebec (which is the government of a province of Canada) to the Supreme Court of Canada (one of the three arms of the Government of Canada). Every single member of this court was, quite understandably, an appointee of the executive arm of the Government of Canada. The vast majority of the members of this court were, as understandably, natives of other provinces in Canada (as opposed to natives of Quebec). Every single member of this court was of course a public servant in the Government of Canada. ${ }^{97}$

Given these features of the processes adopted in the Quebec and Katanga cases, it is fair to conclude that the model of secessionist dispute resolution that is symbolized by the Katanga case tended to be triadic, while that symbolized by the Quebec case tended to be dyadic. As compared to the model symbolized by the Katanga case (i.e. adjudication by an international tribunal), the model

94 For more on this body, see R. Friedland, A Guide to African International Organizations (London: Hans Zell, 1990); and C.O.C. Amate, Inside the OAU: Pan-Africanism in Practice (London: Macmillan, 1986).

95 No one member of the Commission may hail from the same state. There is also a requirement that the different regions of Africa be represented on the commission. See Article 32 of the African Charter, supra note 38 .

96 See Rules 109 and 110 of the Amended Rules of Procedure of the African Commission on Human and Peoples' Rights, 6 October 1995, reproduced in (1996) 8 African Journal of International and Comparative Law 978. These Rules were adopted pursuant to Article 42(2) of the African Charter, supra note 38 .

97 See N. Rosiers, 'From Quebec Veto to Quebec Secession: The Evolution of the Supreme Court of Canada on Quebec-Canada Disputes' (2000) 13 Canadian Journal of Law and Jurisprudence 171 at $171-172$. 
symbolized by the Quebec case (i.e. adjudication by a domestic tribunal that is an intrinsic component of the relevant domestic government), seems to be much more triadic. Thus, the Katanga model seems to be much more in keeping with the basic tenets of fundamental justice already discussed. We must keep it in mind though that what is being critiqued here is the adjudicative model that is symbolized, as opposed to the particular case that symbolizes that model.

If this conclusion is correct, then it is also logical to conclude that the Quebec model is open to the same kinds of concerns, regarding the deployment of dyadic models to the field of secessionist dispute management, that have already been discussed. It is also fair to deduce that, whatever other problems it might have, being relatively much more triadic, the Katanga model is far more immune from the kinds of concerns regarding fundamental justice and popular legitimacy that have already been raised. It is also fair to conclude that, all other things being equal, from a legitimacy perspective, the Katanga model is a better general model for the management of secessionist disputes, especially in those societies that are, as a factual matter, much more deeply fragmented than others. ${ }^{98}$ For, as has already been shown, the more triadic a model of secessionist dispute management, the more it is likely to satisfy the basic requirements of fundamental justice, and the less it is likely to be viewed widely as unfair, illegitimate, or both. Put differently, the failure of a secessionist dispute management process to adhere closely with the spirit if not the letter of any of the basic tenets of fundamental justice is likely to foster perceptions of inherent unfairness and illegitimacy in the minds of the perceiving public. While this sort of negative perception is likely to be more rampant among the membership of the aggrieved sub-state group, who will most likely be the losing side, legitimacy suffers still. The popular legitimacy of the secessionist dispute management process suffers because such a system's credibility and fairness is largely dependent on how it is perceived by the losing (not the winning) side.

The conclusion that the Katanga model is on the balance preferable was reached not merely because of the failure of the more dyadic model (symbolized by the Quebec case) to accord with one of the basic formalistic requirements of fundamental justice (i.e. that nemo judex in causa sua). It was reached principally because of its greater potency to ignite charges of

98 While such deeply societies are not of course confined to the so-called 'third world', the peculiar colonial histories of these states has resulted in the more frequent incidence of deeper then usual fragmentation within their territories. By suddenly agglomerating thousands of previously independent and distinct polities, with very little attention paid to their own political choices, colonial expansionists all but ensured that the successor 'third world' states would be afflicted from the beginning by a crisis of legitimate statehood. Moreover, the leaders of these successor states have failed in the drive to deal effectively with these crises of legitimate statehood. Having said that, it is also clear from incidents in places like Bosnia, Northern Ireland, and Spain that deep fragmentation is a global phenomenon. and See O.C. Okafor, Re-Defining Legitimate Statehood, supra note 12. 
unfairness and illegitimacy, and the crucial role that is played all-too-often by perceptions of unfairness and/or illegitimacy in the degeneration of highly charged political disputes (such as those concerning secessionist claims) into violent conflicts. Thus, the foregoing argument is not simply an inflexible formalist contention that the 'third party-ness' of a secessionist dispute manager must invariably determine the perceived legitimacy of the entire model or process of adjudication. The argument forwarded here is that in the deeply fragmented societies in which most of the world's secessionist claims are made the 'third party-ness' or otherwise of the secessionist dispute manager assumes a critical place among the complex matrix of factors that influence popular perceptions as to the unfairness and illegitimacy of the process (and even of its outcomes). This is so because, as the literature already tells us, in such much more deeply fragmented societies, deep distrust of the organs of the central government are usually rife among the secessionist sub-state group, and are more often than not quite justified. In this sense, any significant negative decision that is made by an arm of the central government regarding the secessionist ambitions of such sub-state groups is likely to be greeted with often well-deserved scepticism, if not violent resentment. Yet central governments, including their judicial arms, are more likely to oppose, rather than support the secessionist ambitions of their sub-state groups.

It is of course recognized, as many scholars already have, that the model of secessionist dispute management symbolized by the Quebec case did (at least in the end) serve Canada and Canadians quite well, and elicited relatively very little outrage among even secessionist minded Quebecois. ${ }^{99}$ But this may be largely attributable to the fact that in the instant case the court kept to relatively safe and generally accepted ground. ${ }^{100}$ Moreover, the judgement offered 'something' to each side of the dispute; something that they could identify as a victory for their cause, something that resonated for them. ${ }^{101}$ In addition, the court 'injected a welcome note of civility into our [i.e. Canadian] constitutional introspection', ${ }^{102}$ and conceptually eliminated extremists on both sides from the political agenda. ${ }^{103}$ All in all, allowing for a few uncivil

99 See B. Ruder, supra note 92 at 9.

100 See D.P. Haljan, 'A Constitutional Duty to Negotiate Amendments: Reference Re Secession of Quebec' (1999) $48 I C L Q 447$ at 455.

101 See M. Dawson, 'Reflections on the Opinion of the Supreme Court in the Quebec Secession Reference' (1999-2000) 11 National Journal of Constitutional Law 5 at 6. See also M. Moore, 'The Ethics of Secession and a Normative Theory of Nationalism' (2000) 13 Canadian Journal of Law and Jurisprudence 225 at 246.

102 See A.C. Cairns, 'The Quebec Secession Reference: The Constitutional Obligation to Negotiate' (1998) 10 Constitutional Forum 26.

103 See R.A. Young, 'A Most Politic Judgement' (1998) 10 Constitutional Forum 14 at 15-16. 
incidents such as the FLQ crisis in the 1970 s, ${ }^{104}$ Mary Dawson is mostly right to suggest that:

'This Reference should be a source of pride... it is wonderful that Canada is a country [today] where such highly charged issues as the potential secession of one of its provinces can be taken to its highest court. ${ }^{, 105}$

Thus, in this particular Canadian case, the dyadic model seems to have worked as well as a triadic model could possibly have. ${ }^{106}$ But this testifies more to the relative civility of contemporary Canadian secession politics than to the desirability of generalizing the more dyadic model of secessionist dispute management to other lands. Moreover, had the court found that under no circumstances whatsoever was Quebec entitled to secede from Canada, the outcome, legitimacy wise, may have been quite different.

Thus, for the reasons that have already been adduced, one cannot be sanguine about the likelihood of that more dyadic model working in the same way in societies that are much more fragmented and divided than Canada. Moreover, despite the rarity of instances of incivility in the struggle over the secession of Quebec from Canada, one could not be sanguine about the capacity of the dyadic model of secessionist dispute management that is currently favoured by the Canadian government to survive the severe denudation of its legitimacy that might result from sustained accusations of procedural unfairness and inherent illegitimacy. This point is buttressed by the halo of suspicion (among the people of Quebec) that surrounded the very decision of the Government of Canada to refer the case to the Supreme Court of Canada. As Robert Young has noted, during the relevant period:

'Among [Quebec] nationalists, some headway - perhaps a lot of headway could be made using the argument that the court ruling, emanating from judges appointed by Ottawa, would put [French] Quebecois into a straight jacket tailored in English Canada. ${ }^{107}$

Indeed, at the time the case was referred to the court by the Government of Canada, a political advertisement placed in the media by the Government of Quebec pointedly described the Supreme Court of Canada as much like the 'Leaning Tower of Pisa' that leans only in one direction (in this case - in the direction of the anti-secession cause of the Government of Canada)! ${ }^{108}$ In fact,

104 See L. Fournier, F.L.Q.: The Anatomy of an Underground Movement (Toronto: NC Press, 1984).

105 See M. Dawson, supra note 101 at 6.

106 But see the somewhat dissenting voices of S. Toope, supra note 29; and G. Millard, 'The Secession Reference and National Reconciliation: A Critical Note' (1999) 14 Canadian Journal of Law and Society 1 at $1-2$ and 18.

107 See R.A. Young, supra note 103 at 15.

108 Ibid. See also N. Des Rosiers, supra note 97 at 172. 
the Government of Quebec had from the very beginning hinged its refusal to participate in the hearing of the case on this clear challenge to the fairness of the very decision to refer the case to the court, and the legitimacy of the court's role as the secessionist dispute manager. ${ }^{109}$

Legitimacy is thus likely to be seriously compromised by the deployment of a more dyadic model to the delicate task of secessionist dispute management between a state and one or more of its sub-state groups. The more triadic model, especially one that makes use of an agency external to the state (such as an international tribunal) is more likely to avoid the specific legitimacy deficits that attend the use of the dyadic model in deeply fragmented societies. It is in this specific sense, that the Katanga case symbolizes a model of secessionist dispute management that is preferable both from legitimacy-based and pragmatic perspectives (especially as concerns states that are, as a factual matter, much more deeply fragmented usual). As we have already seen, the more dyadic model (according to which the courts - an arm of the government determine even the most highly charged political disputes between citizens/ groups and the very same government) is ubiquitous across the globe. But from an ethical and pragmatic perspective, its ubiquity does not necessarily ensure its desirability. While the deployment of more dyadic models to the management of even the most highly charged secessionist disputes may be legal virtually everywhere, and while such a posture is certainly a better way of managing such disputes than the deployment of violence, such a practice is not always pragmatically or ethically desirable. The issue here is not so much the entitlement of states to use the Quebec model, but the ethics and pragmatics of the matter. And this concern is worthwhile precisely because in no society (rich or poor, fragmented or unified) is the insistence on 'a legality that is stripped of any ethical concerns"10 either practicable in the long run or conducive to sustainable peace. That is why the principles of fundamental justice (derived as they are from widespread understandings of ethical and pragmatic imperatives) are viewed as sacred in virtually every legal system.

The importance of substantial fidelity to this ethical/pragmatic imperative becomes even more palpable in the context of the crisis of legitimate statehood that currently afflicts the vast majority of states in the world. In the face of the intense centrifugal forces generated by the restiveness of aggrieved minority or oppressed sub-state groups, many states are under intense pressure to secure peaceable ways of retaining such groups within their borders. One such method is the management of the dispute by one or more of the very institutions of the relevant central government. This has been the preferred approach virtually everywhere in the world: from Canada to the Cameroons, from Nigeria to

109 See B. Ryder, supra note 92 at 9-10.

110 See J. Leclair, 'Impoverishment of the Law by the Law: A Critique of the Attorney-General's Vision of the Rule of Law and the Federal Principle' (1998) 10 Constitutional Forum 1 at 3. 
Mexico, from Senegal to Spain, and from Britain to Belgium. Yet, all-toooften, the central issue at stake is the structural alienation of such sub-state groups from the institutions of the state of which they are a part. All-too-often, it is these very institutions that have been used to exclude, oppress, or suppress minority or powerless sub-state groups. All-too-often, these institutions are not representative of the diversity of the relevant country. Given the intolerant character of many such state institutions, it is hardly surprising then that many such groups feel fundamentally excluded from the political and judicial institutions of the relevant central government. It is not surprising as well that many such groups have a deep-seated distrust of the institutions of the central government (including the courts of law). In such contexts therefore, it is hardly unreasonable to suggest that a more triadic model of secessionist dispute management, especially one that is presided over by an external or international third party, will be much more acceptable to aggrieved minority or powerless sub-state groups than a more dyadic model that is presided over by an arm of the very central government that is deeply distrusted by the substate group. It is also hardly unreasonable to suggest, in that context, that the more triadic model will, all things being equal, be more capable of fostering a process and outcomes that are widely viewed as fair and legitimate. If this is so, then the more triadic model is also more likely, in such contexts, to lead to a more sustainable solution to the crisis of legitimate statehood that afflicts the relevant state. In this way will the overall interests of both states and minority/ powerless sub-state group be better served, at least in the long run.

It must be noted, however, that my argument in favour of a more triadic, more external, more detached third party arbiter of secessionist disputes must be constrained by a healthy restraint from too quickly resorting to global-level (as opposed to regional-level) mechanisms for the management of such disputes (especially those that occur in the so-called 'third world'). There are a number of reasons why this might turn out to be ill advised, but this paper will deal with only two. The first is that, because the history of (especially unilateral) global-level intervention in such matters is, in general, an unhappy one, it would be better to deploy regional-level mechanisms, warts and all, in such cases. ${ }^{111}$ The idea will be to try something that seems somewhat novel in international relations: the provision of a sustained opportunity to regionallevel institutions in the 'third world' to 'own' and operate their own secessionist dispute management mechanisms. Regional-level mechanisms are rarely afflicted with the kind of 'ownership' problems that have weakened most global-level interventions. ${ }^{112}$ Again, regional-level mechanisms are much better equipped with the necessary knowledge base and sensitivity to local 
desires without which an intervention in a high stakes political dispute (such as one regarding secession) will be highly problematic. ${ }^{113}$ And lastly, regionallevel mechanisms suffer less from the credibility problems that mechanisms that are external to the 'third world' suffer when engaged in interventions there. ${ }^{114}$ For all of these reasons, it may be better to think of global-level mechanisms as a last resort, to be deployed only when regional-level mechanisms are not likely to escape the kind of legitimacy problems that have already been identified.

\section{Conclusions}

This paper advanced at least three major arguments. The first is that the decision in the Katanga case has left very little room for continued doubt as to the meaning of Article 20 of the African Charter. And that regardless of our individual views as to the justifiability of secession, Article 20 must now be viewed as permitting, in the context of the regional international law applicable to Africa, a limited treaty-based entitlement to secession in some highly exceptional cases. The second is that the decision in the Quebec case is judicial confirmation of the emergence, as part of global international law, of a highly circumscribed entitlement to secession. The Quebec decision did not create this entitlement, it merely affirmed its existence and grounding in a number of existing treaty and soft-law instruments. The third is that the model of secessionist dispute management that is symbolized by the Quebec case is highly problematic from the legitimacy perspective. This is because of a major ethical problem that confronts that model: i.e. its substantially dyadic (as opposed to triadic) character; one in which an arm of the more powerful party to the dispute is also the arbiter of the secessionist dispute. It was also shown that, concomitantly, the model that is symbolized by the Katanga case is preferable (from a legitimacy perspective) largely because of its much more triadic character. For, its triadic features ensure the presence of a more external, more detached, third party arbiter. This is so despite the relative success of the Quebec model in the peculiar space-time context in which it was operated. For, we must remain extremely cautious regarding the applicability of the dyadic model in societies that are more deeply fragmented than others. This is one circumstance in which a little caution would be healthy. 